\title{
The development of tomatillo (Physalis ixocarpa Brot.) in Polish conditions. II. Flowering and fruiting.
}

\author{
LESZEK S. JANKIEWICZ and JAN BORKOWSKI
}

Research Institute of Vegetable Crops, ul. 22 Lipca 1/3, 96-100 Skierniewice, Poland.

(Received: April 15, 1988)

\begin{abstract}
The reproductive development of tomatillo (husk tomato) was investigated in the conditions of central Poland. The developmental cycle of tomatillo in Poland lasts 20-23 weeks, including 6 weeks in a greenhouse or a tunnel and is longer than in Mexico ( 15 weeks). The plant grows well in Poland and is fruiting aboundantly. The cv. Rendidora B1 was early fruiting and sensitive to drought so it should be cultivated in a garden. Cvs. Bujna and Antocyjanowa were medium late or late and suitable for open-field cultivation. Fruit development lasts about 6 weeks. Fruiting was concentrated on the apparent lateral branches of the $1 \mathrm{st}$ and 2 nd order during the large part of a vegetative season. Among the abscised generative organs predominated flowers and at the end of vegetative season the flower buds. The maximum abscission of flower buds and flowers took place about 2-4 weeks after the most intensive flowering and fruit set. The fruits of many individuals are easily cracking. After being abscised they are attacked frequently by Botrytis sp.
\end{abstract}

\section{INTRODUCTION}

Tomatillo (husk tomato) is a plant widely cultivated in Mexico. It was introduced in 1982 to Poland. Its development was described in Mexico by S a r a y - M e z a (1977), M u l a t o - B rit o et al. (1985) and C art u ja n o - E s c o b a r et al. (1985). These papers concern the Mexican cultivar Rendidora.

We took three cultivars: Rendidora B1 which originates from the Mexican cv. Rendidora, and two others not yet investigated: Antocyjanowa and Bujna (for the description see J a n k e w i c z and B or k ow s ki, - in print). 
The vegetative growth of tomatillo, as well as the agricutural practices which we have followed in Poland are described in the first part of this paper ( $\mathrm{J}$ a $\mathrm{n} \mathrm{k}$ i ew i c z and B or k ow s ki, in print). Tomatillo plant forms four apparent main axes, which at each node, form apparent lateral axes of the first order, these in turn, form lateral axes of the second and third order. The another characteristic trait of tomatillo is that in each node, a single flower bud is formed (exept few inicial nodes when a plant is still juvenile) (Fig.1). After some years of cultivation and processing of tomatillo we are more and more convinced that this plant will gain the constant position among Polish vegetables. It seemed therefore worth-while to investigate flowering and fruiting habit of this plant in Poland.

\section{MATERIAL AND METHODS}

The weather and soil characteristics as well as the methods of cultivation were described earlier ( $\mathrm{Ja} \mathrm{k} \mathrm{i} \mathrm{e} \mathrm{w} \mathrm{i} \mathrm{Cz} \mathrm{and} \mathrm{B} \mathrm{or} \mathrm{k} \mathrm{o} \mathrm{w} \mathrm{s} \mathrm{k} \mathrm{i,} \mathrm{in} \mathrm{print).} \mathrm{It} \mathrm{seems}$ pertinent to recall, however, that the measurements of the plants were done every two weeks if no other-wise indicated. It is also important that the plants were transplanted into two places: garden were they were irrigated when necessary and were protected from wind, and into open field without irrigation. The plants of the cultivars Bujna and Antocyjanowa were growing after transplantation only in the open field, the plants of Rendidora B1 in the field and in the garden. The fruits with the diameter less then $2 \mathrm{~cm}$ we will call "fruitlets" in the further text and those larger than $2 \mathrm{~cm}$. fruits".

\section{RESULTS}

Fruit growth was observed in 1987 in 'Rendidora B1' plants growing in the garden. Initially, the fruits were growing more intensively in length then in diameter (Fig. 1). After about 2 weeks from the moment when we started measurements their growth in longth terminated whereas their diameter continued to augment for about 25 days more, so that finally the fruits were almost round or a little flattened (Fig. 1). The growth of a fruit lasted therefore more than 6-7 weeks (we have started measurements when the fruits had already $1-1,5 \mathrm{~cm}$ in diameter).

The dynamics of flowering and fruiting and the fertility of particular axes of tomatillo plant were investigated. 


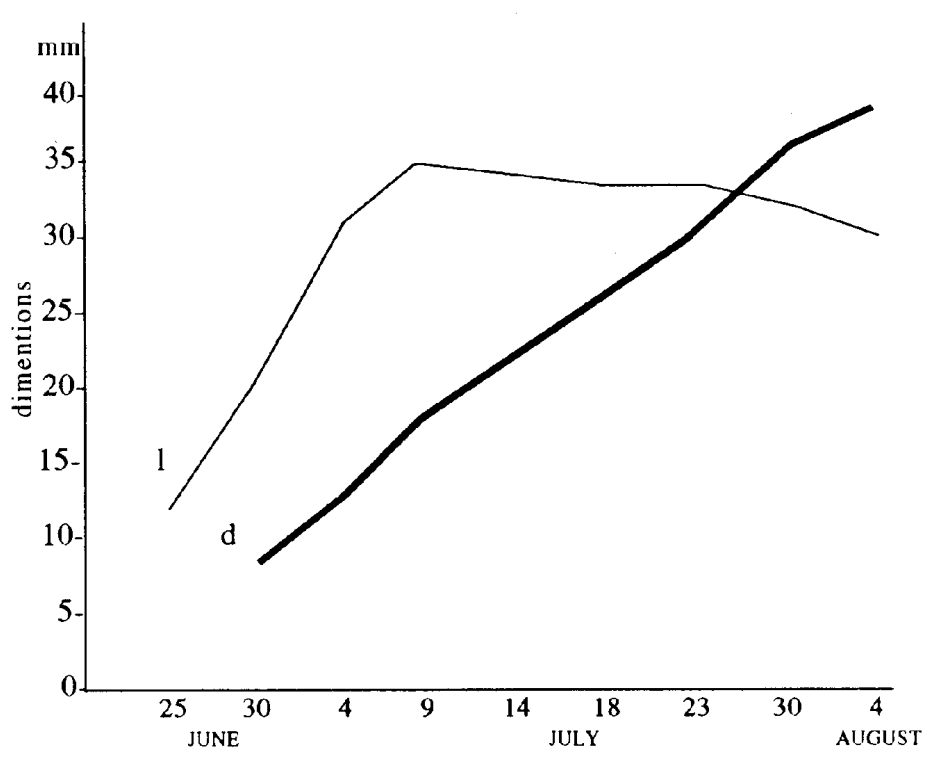

Fig. 1. Growth of tomatillo fruit $\mathrm{cv}$. Randidora B1. Averages of 10 fruits l- length of the fruit, d-diameter

In 'Rendidora B1' plants growing in 1986 in a garden, (Fig. 2) the flowering started at the begining of June reaching pronounced maximum on July 8 th. Thenafter the number of flowers found on the plant diminished drastically. Nevertheless some flowers were found even during the last dates of observation. First fruitlets (diameter less than $2 \mathrm{~cm}$ ) were observed already on June 9 th, maximum number of them was found on July 24 th, i.e. about two weeks after the maximum of flowering. Toward the end of August and during the first decade of September their number was very small. The fruits with the diameter larger than $2 \mathrm{~cm}$ were observed first on June 23 rd and their number was the largest on July 24 th and August 7 th. They occured in a relatively high number even at the two last dates of observation.

Flowering and fruiting took place on different axes (Fig. 2). Initially flowering was concentrated in $\mathrm{cv}$. Rendidora B1 the main apparent axis and on the lateral axes of the 1 st order. Later on, the flowering was concentrated primarily on the lateral apparent axes of the $1 \mathrm{st}$ and 2 nd order and usually there were more flowers on the axes of the 2 nd order. The lateral apparent axes of the 3 rd order formed flowers in significant number only during July, i. e. during the most aboundant flowering of the whole plant. 


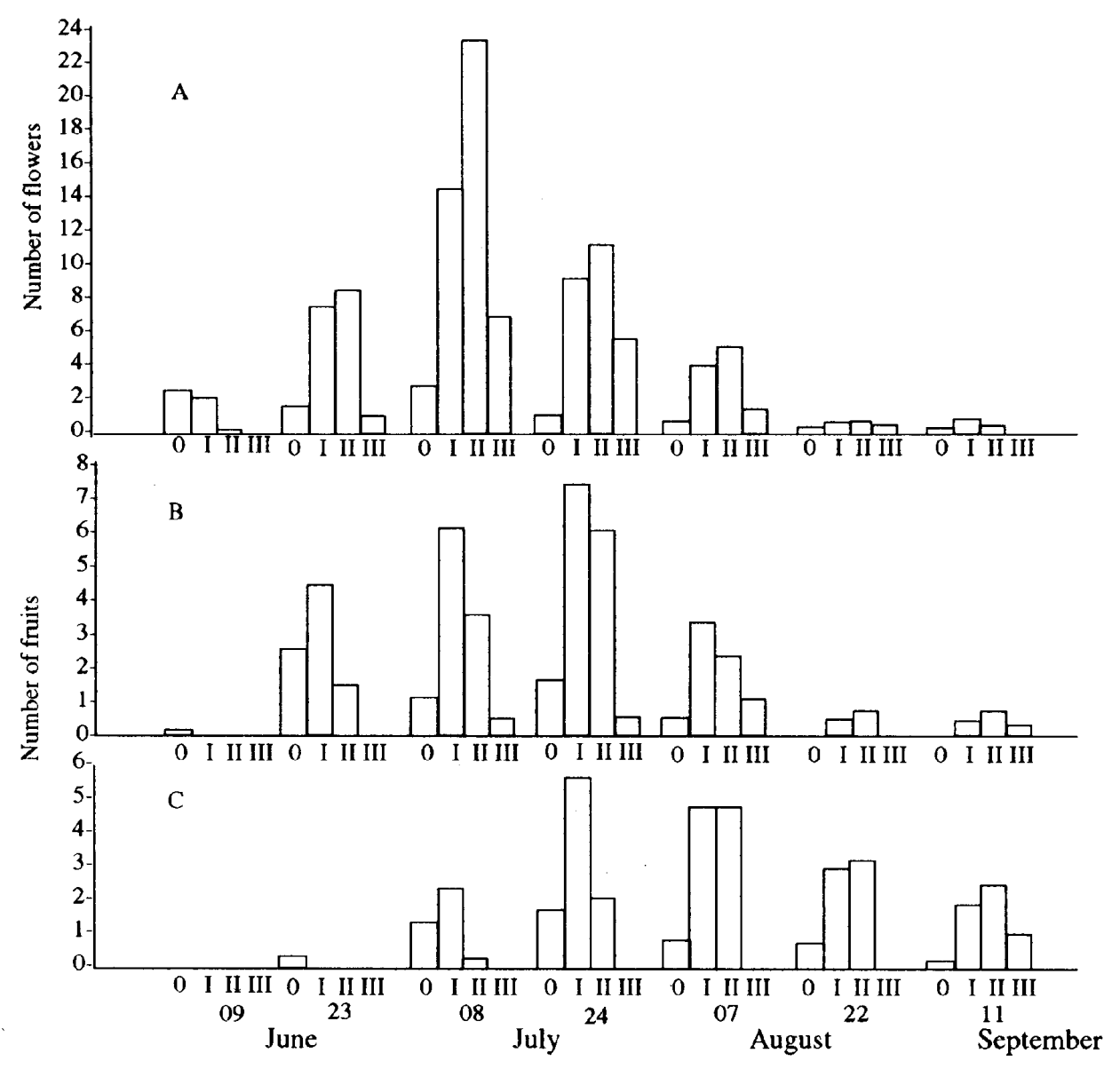

Fig. 2. Cultivar Randidora B1 growing in a garden in 1986

A - thew number of flowers, B - number of fruillets (diameter less then $2 \mathrm{~cm}$ ), C-number of fruits (diameter more then $2 \mathrm{~cm}$ ), 0,1, II, III - the main apparent axis and the lateral branches of the $1 \mathrm{th}, 2 \mathrm{nd}$, and $3 \mathrm{rd}$ order, respectively

The fruitlets were most abundant, initially on the apparent branches of the 1 st order and on the apparent main aix (see the date 06.23) and later on, on the branches of the 1 st and 2 nd order. Always, however, except the two last dates of observation, there was more fruitlets on the branches of the 1 st order than on these of the 2 nd order. The comparison with the distribution of flowers indicates that the flowers formed on the branches of the 1st order are more fertile, probably due to better nourishement or better pollination.

The fruits larger than $2 \mathrm{~cm}$ were most abundant initially on the apparent lateral axes of the 1st order and on the apparent main axis, and later on the axes of $1 \mathrm{st}$ and 2 nd order. The fruits of this class were found on the branchesof the $3 \mathrm{rd}$ order only during the last date of observation. 

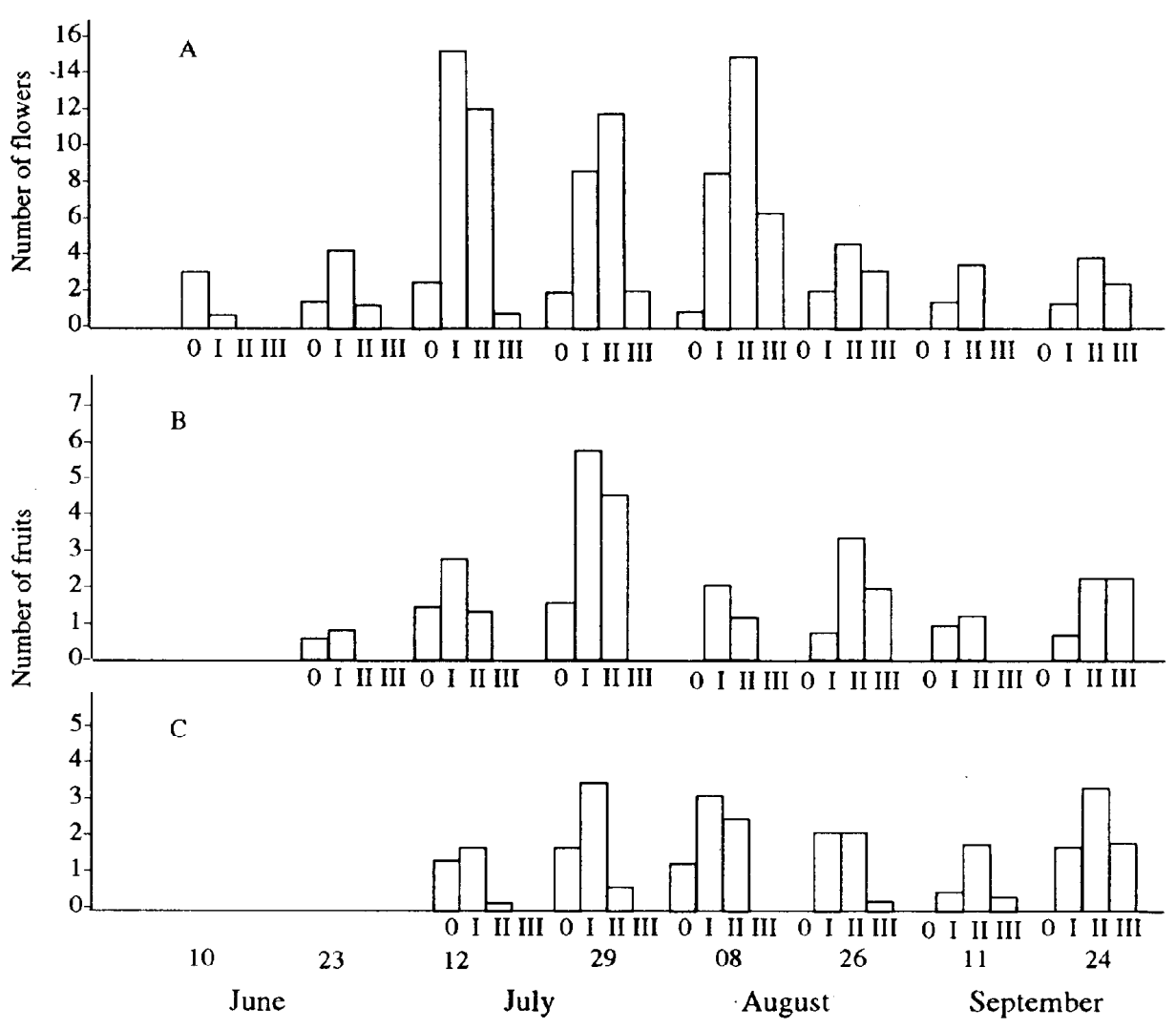

Fig. 3. The number of generative organs in a plant of cv. Rendidora B1 growing in the field in 1986 Other details as in Fig. 2

The plants of 'Rendidora B1' growing in the field in 1986 (Fig. 3) formed some flowers already on June 10 th. Large quantity of flowers was found on them on July 12 th and on August 8 th. Flowering was supperssed on July 29 th during the droughty weather. The first fruitlets were found on June $23 \mathrm{rd}$. There was a marked diminution of the number of fruitlets on August 8 th which suggest that the flowers were not pollinated during the drought preceding this date or were abscised after pollination. Later on, the plants somewhat regenerated and were setting fruits for a longer time than in the garden.

The number of fruits larger than $2 \mathrm{~cm}$ was much smaller than in the plants growing in the garden. There was a slight maximum of their number at the and of July and the begining of August. Also during the last observation date: September 24 th the number of fruits of this class was relatively large. The apparent lateral branches of the 1 st and 2 nd order were most fertile over a most time. 
The plants of the $\mathrm{cv}$. Antocyjanowa growing in the field (not shown in the pictures) behaved like those of 'Rendidora B1' growing in the some conditions. Only the influence of drought was less marked in them.

In 1987 the spring was very late and cold (see J a n k i e w i c z and B o r $\mathrm{k}$ ow s k $\mathrm{i}$, in print). This influenced markedly the development of the plants of 'Rendidora B1' growing in the garden. The maximum flowering took place on July 27 th, i.e. about 20 days later than in 1986. Besides that the behaviour of the plants was similar as in 1986.

The plants of the cultivar Bujna were not observed in detail in 1986, however it seems important that 'Bujna' plants were much more drought-resistant than 'Rendidora $\mathrm{B} 1$ ' and resembled in this respect 'Antocyjanowa'.

In 1987, the plants of one of the types selected among the cultivar 'Bujna' named 'Bujna 2 ' were cultivated in the field. They were growing exuberantly and were fruiting aboundantly (Fig. 4).

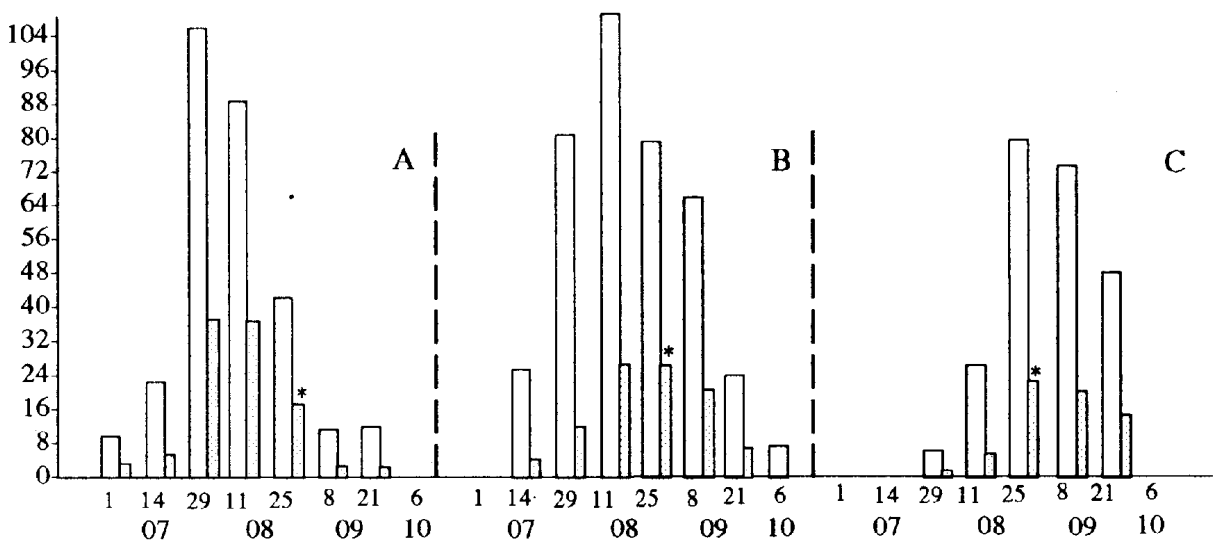

Fig. 4. Flowering and fruiting of 'Bujna 2' plant growing in the field in 1987

Dotted columns - the shoots growing on the true main axis. The columns marked with asterisk are interpolated. Other details as in Fig. 2

Their maximum flowering was observed on July 29 th i.e. at about the same time in the plants 'Rendidora B1' growing in the garden in this year. The maximum number of fruitlets was found 2 weeks later and maximal number of fruits larger than $2 \mathrm{~cm}$ was found about another two weeks later (on August $25 \mathrm{th}$ ), however, relatively aboundant fructification was observed also on September 8 th and September 21 st indicating that 'Bujna 2' is a late cultivar. The branches on the trunk were producing about $20 \%$ of fruits larger than $2 \mathrm{~cm}$ during the last three dates of observations. The participation of these branches was similar in 'Rendidora' plants. The flowering and fruiting was concentrated on the apparent lateral branches of the 1st and 2 nd order (Fig. 5) during most of the vegetative season. 


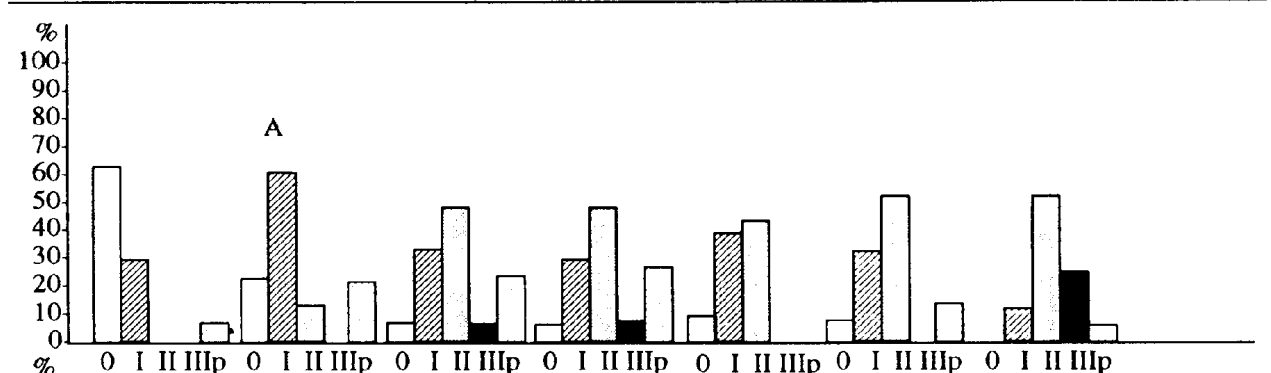
$100-1$

$90-$

$80-$

$60-$ B
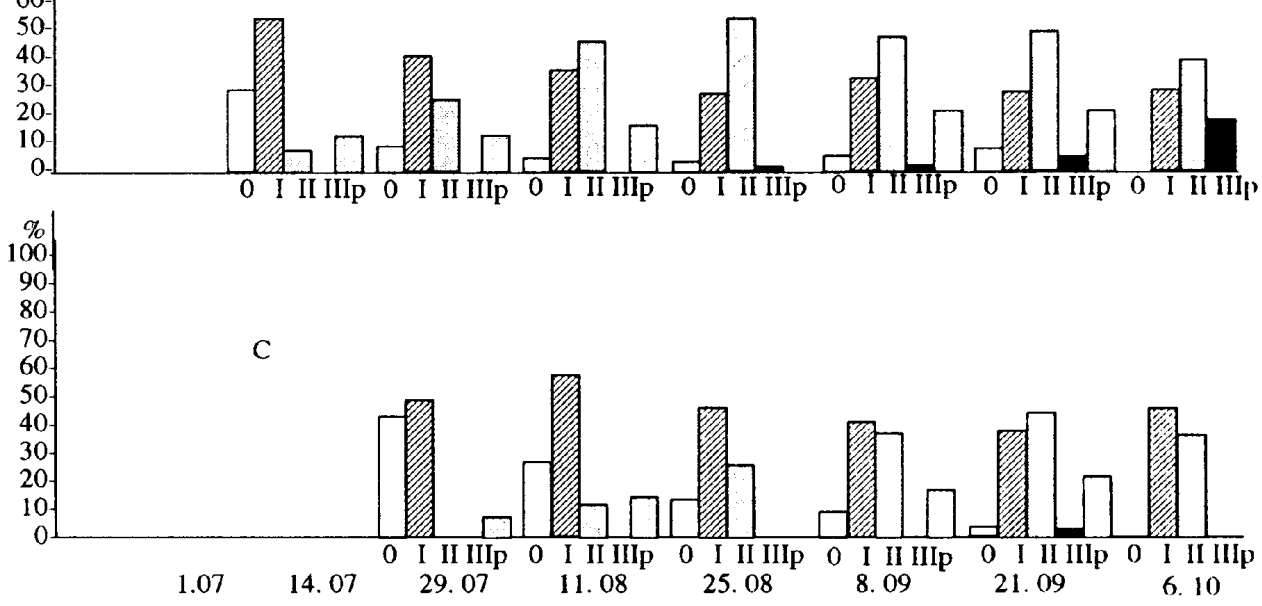

Fig. 5. The participation (in \%) of axes of different order in flowering and fruiting of "Rendidora B 1" plants presented in Fig. 4

$\mathrm{p}$ - shoots growing on the true main axis. Other details as in Fig. 2

Pollination of tomatillo was performed mainly by bumblebees in May and June and by bumblebees and honey bees later. Frequently the number of bumblebees visiting the first flowers was very small and the large proportion of early flowers were not pollinated. This seemed to stimulate the vegetative growth of the plants.

The dynamics of yelding of different cultivars of tomatillo in 1986 is shown in Fig. 6. From these date is visible that 'Rendidora B 1 ' is an early cultivar Bujna is medium late and 'Antocyjanowa' is late. The cv. Rendidora B 1 cultivated in the garden was fruiting more abundantly than in the field. In all cultivars occurred a yield depression in early September which is probably due to the drought occurring a month earlier. In 1987 (Fig. 7) yielding of 'Rendidora B1' was delayed in comparison with 1986. Cultivar Bujna 2 produces much more fruits in the field than the cultivar Rendidora B1 in the garden. 


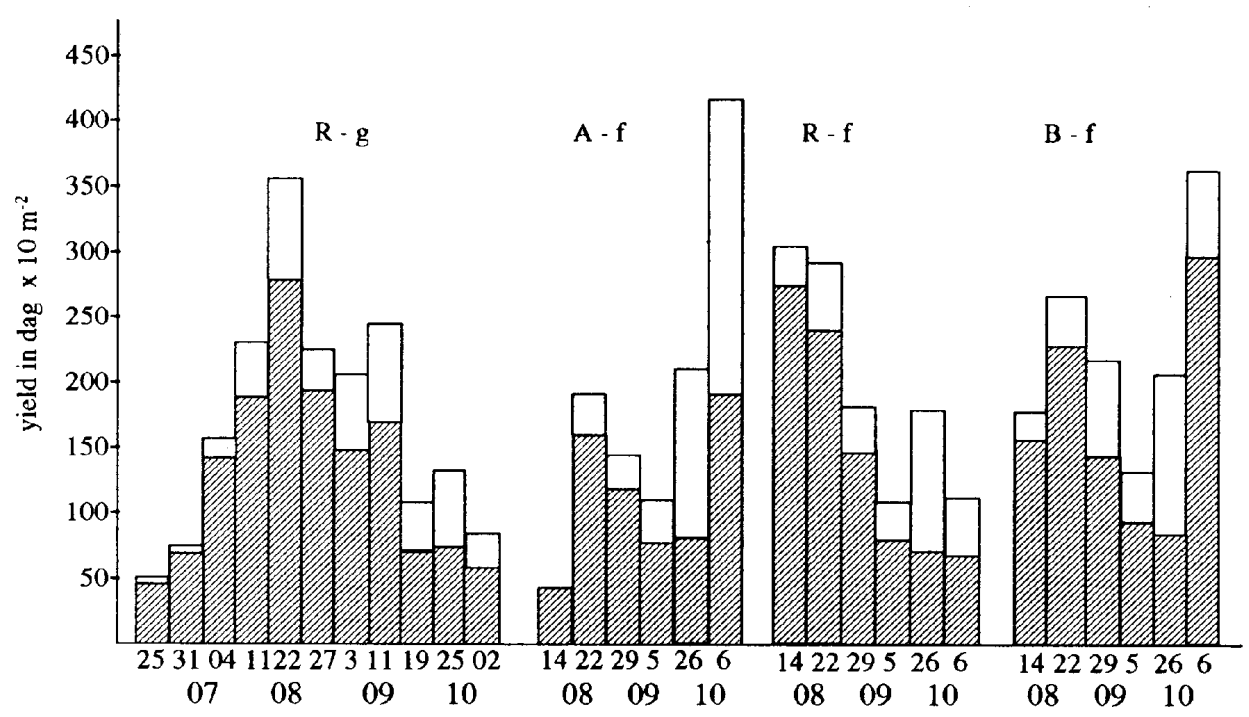

Fig. 6. The dynamics of cropping of tomatillo plants in 1986

R-cv. Rendidora B1, A - cv. Antocyjanowa, B - cv. Bujna 1, g-garden, f-field. Entire columns - total yeld.

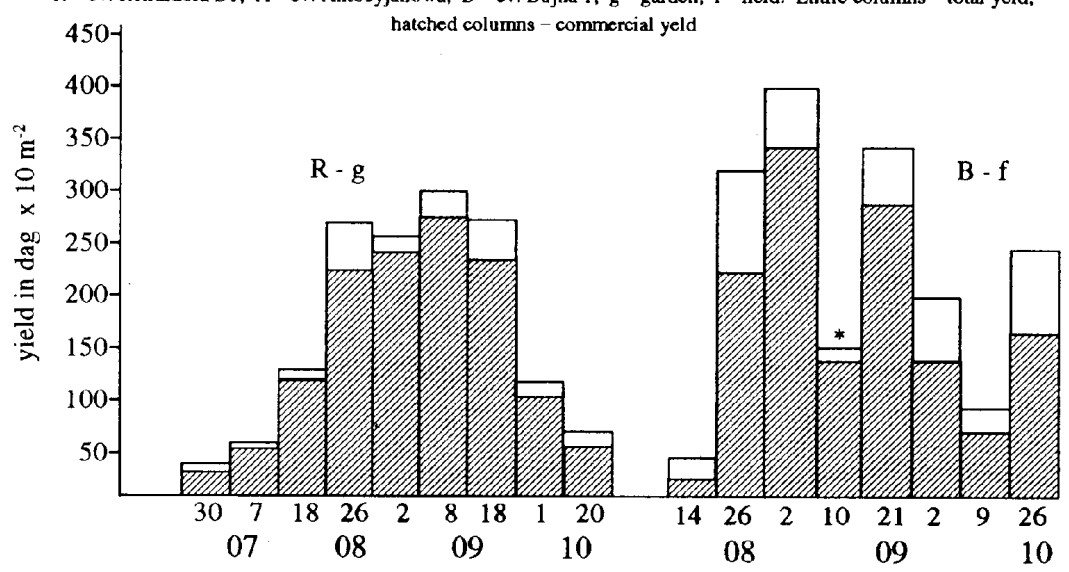

Fig. 7. The same as Fig. 6 but for 1987

Asterisk - the crop partially destroyed

The participation of fruits of different kinds in the crop is presented in Fig. 8. The fruits of the 1 st and 2 nd class (healthy, well shaped with the diameter more than $3 \mathrm{~cm}$ ) consisted large percent of the general crop, especially in 1987. The loses were caused by diseases (gray mold) Botrytis sp. and by a disorder of probably physiological nature the "marble surface". Cracking was an important factor diminishing the quality of fruits. There was, however, graet variability among individuals concerning susceptibility to this disorder. 

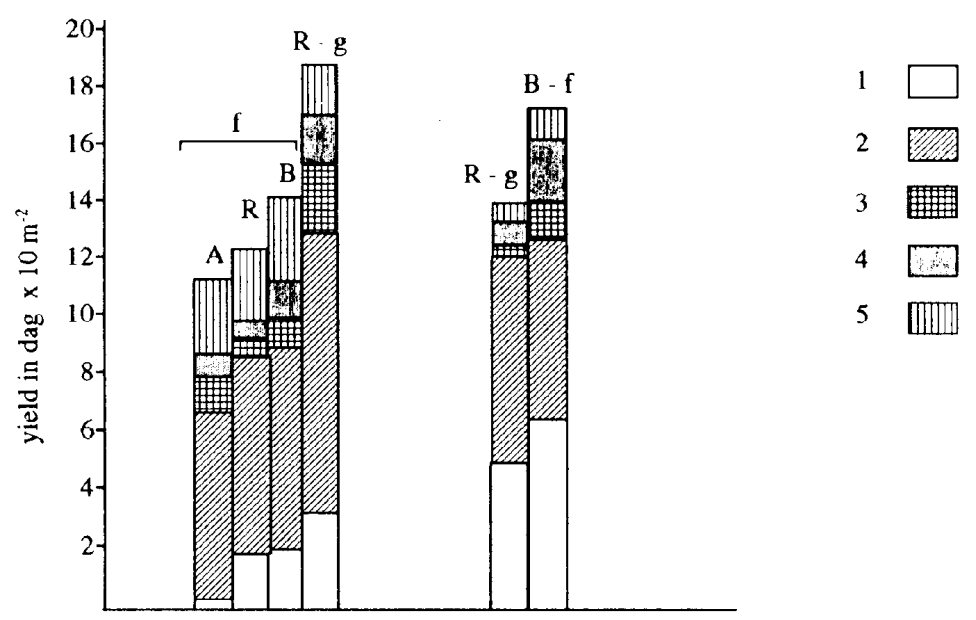

Fig. 8. The participation of fruits of different kind in a crop of tomatilo in 1986 and 1987

1- fruits larger then $4,5 \mathrm{~cm}, 2$ - fruits $3-4,5 \mathrm{~cm}, 3$ - fruits smaller then $3 \mathrm{~cm}$ heal thy, 4 - cracked, 5 - diseased. Other details as in Fig. 6

General crop amounted from about $11 \mathrm{~kg} / 10$ plants $\left(5 \mathrm{~m}^{2}\right)$ in cv. Antocyjanowa up to $19 \mathrm{~kg}$ for Rendidora in the garden and $17,5 \mathrm{~kg}$ for Bujna 1 in a field what was equivalent to 22.38 and 35 tha respectively.

Abscission of generative organs of 'Rendidora Bl' plants during the vegetative saeson of 1986 is presented in Fig. 9. The maximum number of abscised organs was registered on August 7 th, i.e. about one month after the maximum of flowering (compare Fig. 2), and about 2 weeks after reaching the maximum of fruitlet number on the plant. However, maximum of abscission coincides with the date when the greatest number of fruits larger than $2 \mathrm{~cm}$ were present on the plant. Later on, during the late August and September the abscission of flower buds and flowers was still considerable, so that the number of generative organs encountered on the plant was very low.

During all dates of observations, mainly the flowers were shed. The buds were abscised in significant amount since early July but their participation in the whole number of abscised organs became more conspicuous toward the end of vegetative season. Some fruitlets of the diameter less than $1 \mathrm{~cm}$ were shed all over the vegetative season except the earliest dates, for instance $23 \mathrm{rd}$ of June. Probably some of them were the defective fruits, not fully pollinated etc. The fruitlets of the diameter 1-2 cm were rather persistent. Among the fruits larger than $2 \mathrm{~cm}$ those which attained ripeness and were not collected for some time, were shed. Normally they were shed with the calice envelope, therefore the dehusking before processing may present a problem. The large fruits break usually the calice envelope, whereas the small ones were completly enclosed in it. 


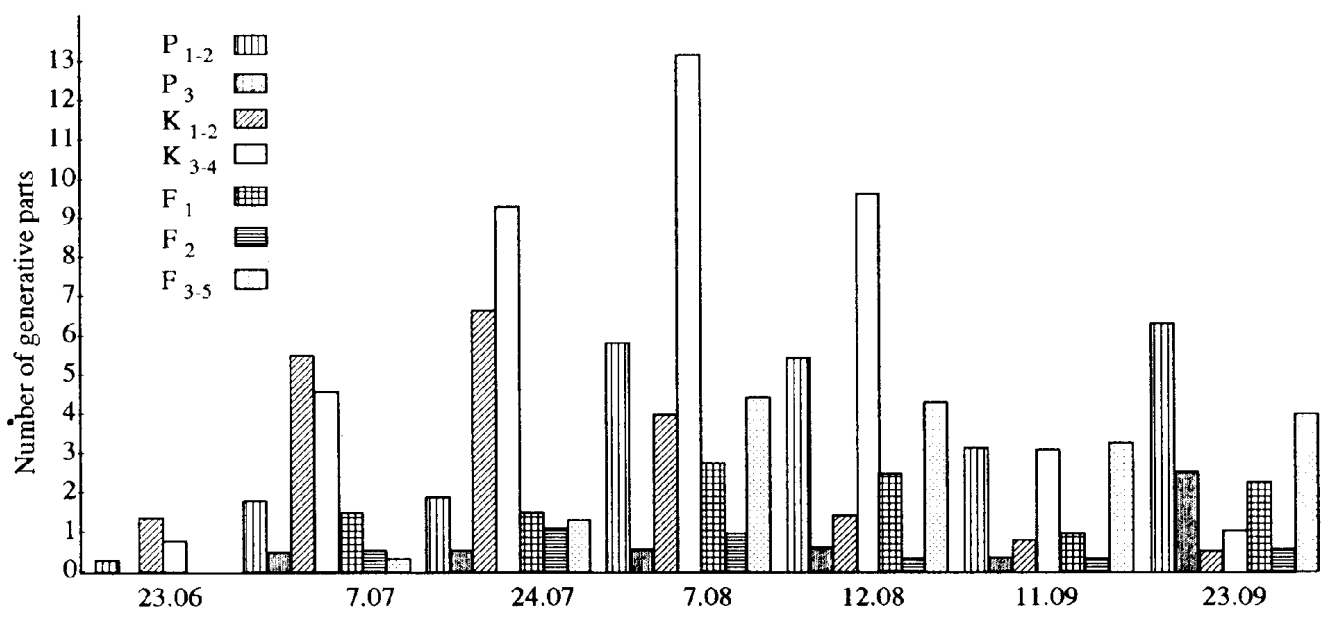

Fig. 9. Abscission of generative parts in Rendidora B1 plants growing in a garden in 1986

P 1-2 and P 3 - the buds of different sizes, K 1-2- flowers partly opened and completly opened, K 3-4 flowers withered, F 1 - fruites with the diameter less then $1 \mathrm{~cm}, \mathrm{~F} 2$ - fruitlets $1-2 \mathrm{~cm}, \mathrm{~F} 3-5$ - fruits larger then $2 \mathrm{~cm}$

For instance: the flower bud was marked as abscised on July 24 th when it was observed for the last time on the previous date of observation (July 7 th)

Abscission of generative organs in the cv. Rendidora B1 cultivated in the garden in 1987 was similar as in 1986 with the maximum number of abscised organs on August 10 (data not shown in the graph). 'Bujna 2' plants cultivated in the field in 1987 showed similar abscission as 'Rendidora B1' in the some year, but the maximum abscission took place relatively late, on August 25 th. Toward the end of the vegetative season all kinds of fruits were easily abscised even those with diameter 2-3 cm (Fig. 10): 'Antocyjanowa' plants was sheding generative organs in very low percent (data not shown in a graph). 'Rendidora B1' plants growing in the field in 1986 showed very heavy abscission after the drought (Fig. 11).

The fruits of tomatillo very rarely attacked by fungus diseases when hanging on a plant, but were easily attacked by Botrytis sp. after being collected or when laying on theground, especially during wet weather and when were cracked. The dehusked fruits stored separately in room temperature may be kept for some monthes and do not show shriveling and most of them do not suffer from roting.

Cracking of fruits was a serious problem in tomatillo but fortunately there as zreat variability concerning this character. Some individuals had non-cracking fruits.

Some fruits showed a light and hard, marble-like superficial discolorations of unknown origin. We do not know if this is a physiological disorder or an effect of parasite attack. 


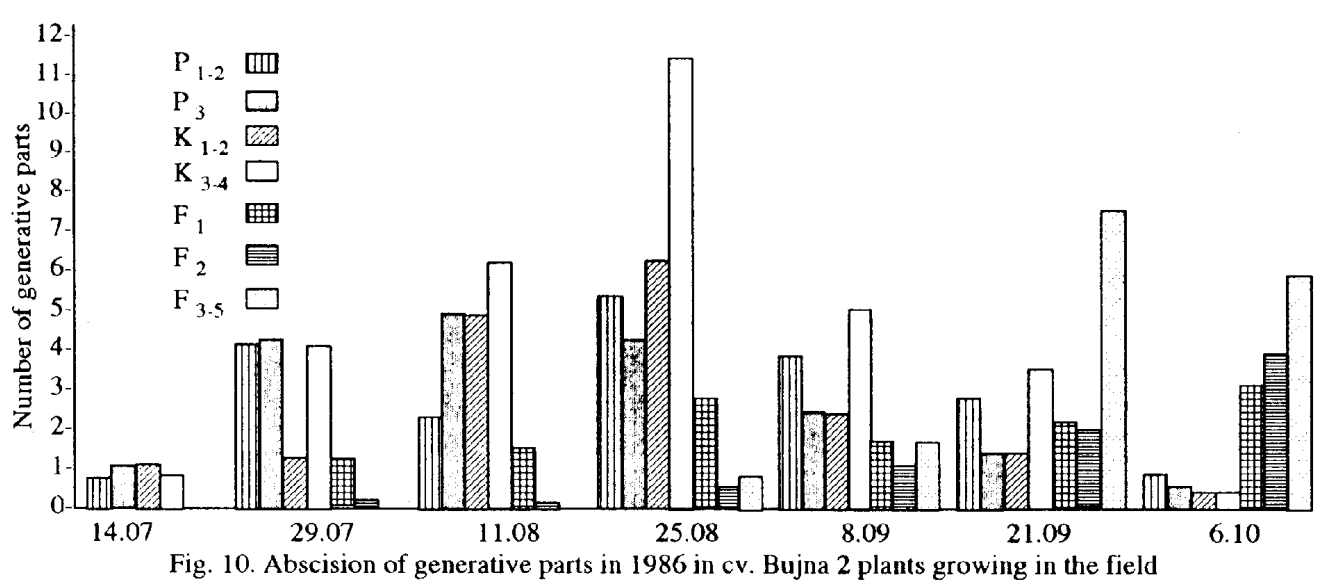

(Details as in Fig. 9)

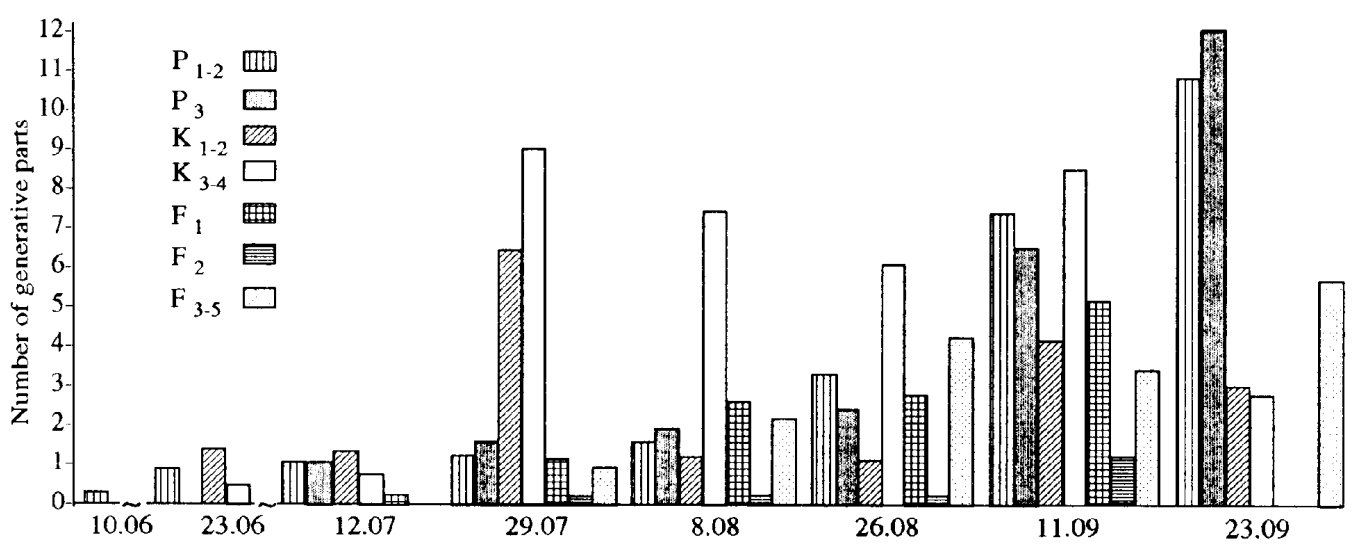

Fig. 11. Abscission of generative parts in 1986 in cv. Rendidora B1 plants growing in the fields (Details as in Fig. 9)

\section{DISSCUSION}

The results on the development of tomatillo received in Poland presented in this paper may be compared to those received in Mexico by $\mathrm{M} \mathrm{u} \mathrm{I}$ a t o - B r i t o et al. (1985) and $\mathrm{C}$ a $\mathrm{rt} \mathrm{u} \mathbf{j}$ a $\mathrm{n}$ o- E s c o b a $\mathrm{r}$ et al. (1985). The following differences may be found in tomatillo $\mathrm{cv}$. Rendidora development in the two countries: in Poland the plants were growing more vigorousely and the fruiting took place also on the apparent branches of higher order: 2 nd and even $3 \mathrm{rd}$. In Mexico, the ripe fruits were collected almost exclusively from the apparent main axis and from the apparent lateral axes of the 1 st order. The apparent lateral axes of the 2 nd order shed prematurely almost all flowers and fruitlets. 
In Mexican experiments the shoots developing on the true axis produced fruitlets, but these fruitlets did not grow sufficiently large to be collected for the market. In Polish experiments this class of shoots produced up to about $20 \%$ of fruits larger then $2 \mathrm{~cm}$. M e d v e d e v (1958) mentions that in USRR tomatillo plants grow larger in northern regions.

The drought in 1986 revealed that the plants of $\mathrm{cv}$. Rendidora B1 are much less resistant to the water deficit than those of 'Antocyjanowa' and 'Bujna'. The plants of 'Rendidora B1' were shown earlier to have very shallow root system (M u l a t o - B r i t o et al., 1985). It would be interesting to compare the root system of the three cultivars to check if the observed differences in drought resistance are connected with the depth of their root systems.

In Mexico, the developmental cycle of tomatillo lasted 15 weeks from the showing date. In Poland this cycle was longer and lasted up to 20 weeks for the early cultivars, like 'Rendidora B1' or 'Bujna 1' or up to 23 weeks for the late cultivars like Antocyjanowa, and Bujna 2, Bujna 3 or Bujna 4 (including 5-6 weeks in heated greenhouse and unheated tunnel).

Abscission of generative organs was assessed only indirectly in Mexican experiment. In the present paper attention was given to the dynamics of abscission of buds, flowers and fruits. Rather heavy abscission of flowers buds, flowers and young fruitlets in tomatillo seems to be the mode of auto-regulation of the number of generative organs per plant. Tomatillo is prone to overproduction of these organs. Relatively lower abscission in 'Antocyjanowa' plants may by caused by limited growth of the lateral axes in this cultivar so less nodes and consequently less generative parts are formed.

From a practical point of view easy abscission of ripe tomatillo fruits does not make trouble when tomatillo is cultivated in home gardens. In large scale production this problem may be of considerable importance, especially in the case of mechanical harvesting.

The total crop of tomatillo which we received ranged from $22 \mathrm{t} / \mathrm{ha}$ to $38 \mathrm{t} / \mathrm{ha}$. $\mathrm{S}$ a r a $\mathrm{y}-\mathrm{M}$ e $\mathrm{z}$ a et al. (1978) write that the $\mathrm{cv}$. Rendidora gave in their experiments the total crop 13,7-39,2 tha during 4 years, and 24,6 tha on average. The non selectioned cultivated populations (criollos) gave only 8,1-22,3 t/ha, on average 16,1 tha. Garzon - T i z n a do and Gara y - A l vares (1986) report the crop 38,1 to 43,6 tha in their experiments. Therefore our results are not much worse then those obtained in Mexico.

It is obvious, however, that croping ability of tomatillo may be greatly improved by breeding, due to reach resurces of gens still present in the cultivated populations. 


\title{
REFERENCES
}

Cartujano-Escobar F., Jankiewicz L. S., Fernandez-Orduna V. M., Mulato-B r it o J., 1985. The development of husk tomato plant (Physalisi ixocarpa Brot.). II. Reproductive parts. Acta Soc. Bot. Pol. 54: 339-349.

Cárden as - Ch a ve z I. E. 1981. Aldunas técnicas experimentales con tomate de csscara (Physalis ixocarpa Brot.). Tesis M. C. Colegio de Postgraduados, Chapingo, Mexico.

G a r z on-Tiz n a do J. A., G a r a y-A l va re z R., 1986. Influencia de la densidad de poblacion sobre el rendimiento y calidad de fruto en el cultivar Rendidora de tomate de csscara (Physalis ixocarpa Brot.). Proc. Trop. Reg. Amer. Soc. Hort. Sci. 23: 268-270.

J a n k i ew i c z L.S., B ok ow sk i J., 1989. The development of tomatillo(Physalis ixocarpa Brot.) in Polish conditions. I. Cultivars investigated, growth ofvegetative parts, resistance to diseases. Acta Soc. Bot. Pol.

K l i n a c N. J., W o o d F. H., 1986. Cape gooseberry (Physalis peruviana) Orchardist of New Zealand 59(3): 103.

Medvedev P. F., 1958. Fizalis - Physalis L. [In]: Kulturnaya flora SSSR. Brezhnev D. D.(ed.). Selkhozgiz. Moskva. Vol. 20, pp. 488-501.

Mulato-Brito J., Jankjewicz L. S., Fernandez-Orduna V.M., Cartujano-Es co

bar F., Serran o-Covar rubias L. M., 1985. Growth, fructification and plastochron index of different branches in the crown of the husk tomato (Physalis ixocarpa Brot.). Acta. Soc. Bot. Pol. 54: 195-206.

S a r a y - M e z a C. R., 1977. Tomate de cáscara algunos aspectos sobre su fisiologia en investigación. Campo Agr. Exp. Zacatepec. CIAMEC-INIA-SARH.

Saray-Meza C. R., Pa la cios A. A., Villa un e va E., 1978. Rendidora, nueva variedad de tonate de cáscara. Campo (Mexico) 54 (1041): 17-21

\section{Rozwój Miechunki pomidorowej (Physalis ixocarpa Brot.) w warunkach klimatycznych Polski. II. Części generatywne}

\author{
Streszczenie
}

Rozwój części generatywnych Miechunki pomidorowej badano w wanunkach środkowej Polski. Cykl rozwojowy miechunki jest znacznie dłuższy w Polsce (20-23 tygodnie, włączając w to 6 tygodni w szklarni lub tunelu) niż w Meksyku (15 tygodni). Roślina ta rośnie jednak w Polsce dobrze i owocuje obficic. Odmiana Rendidora Bl owocowała w Polsce wcześnie i była wrażliwa na suszę, więc nadaje się raczej do ogródków działkowych. Odmiany Bujna i Antocyjanowa okazały się średnio późnymi lub późnymi i nadawały się do uprawy w polu. Rozwój owocu trwał około 6 tygodni. Owocowanie bylo skupione glównie na gał̧̨ziach rzekomych bocznych 1 i 2 rzędu. Pomiędzy zrzucanymi organami generatywnymi przeważaly kwiaty i ku końcowi sezonu wegetacyjnego także pąki kwiatowe. Maksymalne zrzucanie pąków kwiatowych i kwialów niało miejsce 2-4 tygodnie po maksimum kwitnienia i zawiazywania owoców. Owoce wielu osobników tatwo pekaja. Po opadnięciu takie owoce sa tatwo atakowane przez szata pleśń (Borrytis sp.). 